\title{
The Polarization of Orientation on Cultural Land Utilization for Ecotourism Development Amongst the Local in Bali Aga of Mount Lesung Region
}

\author{
Putu Agus Haribawa $^{1^{*}}$, Ricky Avenzora ${ }^{2}$, Harnios Arief ${ }^{3}$ \\ 'Graduate School in Ecotourism Management and Environmental Services, Faculty of Forestry, IPB University, \\ Academic Ring Road, Campus IPB Dramaga, Bogor, Indonesia 16680 \\ ${ }^{2}$ Department of Conservation of Forest Resources and Ecotourism, Faculty of Forestry, IPB University, \\ Academic Ring Road, Campus IPB Dramaga, Bogor, Indonesia 16680
}

Received October 7, 2019/Accepted February 24, 2020

\begin{abstract}
The ownership transfer and conversion of cultural lands are a long-standing crucial issue in the dynamics of tourism development in Bali, so efforts to build a harmonious orientation among stakeholders in creating sustainable cultural land utilizations are important. For that matter, this research was conducted to study the phenomenon of polarization orientation on cultural land utilization of ecotourism development in Bali Aga. The assessment of cultural land sustainability was conducted using One Score One Indicator Scoring System analysis, with research aspects including ownership, economic, ecological, socio-cultural, and spatial aspects. In addition, the polarization of stakeholder orientation was measured through perception, motivation, and preference, and then, it was analyzed using Kruskal Wallis and Dunn Tests. The results of One Score One Indicator Scoring System analysis showed that the community had implemented various principles of sustainability in the utilization of cultural land in the Bali Aga region. The sustainable cultural land utilization in the Bali Aga Region has not been fully achieved because the stakeholder orientation on various aspects and assessment criteria still experience polarization. Although the polarization orientation is still at the level of polarization scale, it can trigger future problems if various stakeholder elements do not well minimize the polarization.
\end{abstract}

Keywords: Bali aga, cultural land, orientation, one score one indicator scoring, polarization

*Correspondence author, email: putuagusharibawa@gmail.com

\section{Introduction}

Ecotourism development in the last two decades is very vigorous done by various countries in the world, both developed and developing countries. Ecotourism is considered to encourage the economy of a country without sacrificing the natural environment and socio-cultural environment of local communities (Lascurain, 1996; Lash, 1997; Barna et al., 2011). Countries such as Australia, Malaysia, Costa Rica, and Indonesia are examples of countries benefiting from ecotourism development. Ecotourism contributes at least 5.5\% of Australia's GDP, providing the foreign exchange of about 13.4 billion ringgit per year (equivalent to IDR35 trillion in Malaysia, and creating employment opportunities and economic improvements in Costa Rica (Driscoll et al., 2011; Nugroho, 2011). From theological side, ecotourism $\mathrm{s}$ able to preserve the environment in West Bali-Indonesia National Park and reduce poaching of wildlife and environmental deforestation in Costa Rica (Driscoll et al., 2011; Pangestu, 2013). On the social-cultural side, ecotourism development has been able to protect traditional community areas in MutawintjiAustralia National Park (Nugroho, 2011).
Land utilization that leads to sustainable patterns is an important issue to be raised in discussions about the sustainability of ecotourism development. The importance of land ownership aspects by local communities in land use, as disclosed by Avenzora et al. (2013), became one of the main prerequisites that the world community has been raising in developing the idea of a good and proper ecotourism development. Avenzora (2013) emphasizes that there are seven pillars that must be upheld in building ecotourism, namely: (1) ecology, (2) social culture, (3) economy, (4) experience, (5) satisfaction, (6) memories and (7) education. This is in line with Tuwo (2011), who explained that ecotourism development could be created if all parties can utilize the available land resources in a balanced way between economic, ecological, and sociocultural aspects. In addition, the participation of local communities, providing experiences, memories, and positive satisfaction for tourists is the principle to build ecotourism (Page \& Dowling, 2002; Diarta \& Sari, 2008). Damanik (2015) also added that the aspect of education is an important part in the management of ecotourism because it brings the social mission to awaken humans in 
understanding well the surrounding environment. Panglipuran and Tenganan-Bali Village are one of the successful forms of ecotourism development related to the utilization of land resources for educational attractions that provide income for the surrounding community, experience, satisfaction, and memories for tourists (Ariani, 2011; Imron, 2015; Mahagangga et al., 2016).

Cultural land can be interpreted as land utilized by the community based on local culture and wisdom owned and developed in the community. One of the areas in Indonesia that utilize the land-based on local wisdom in Bali (Ernawi, 2009). The existence of cultural land in Bali is unique and specific because it has a traditional institutional system (Subak, Desa Pakraman, and Banjar) and the ritual ceremony implementation (custom and religious) in every land utilization activity. The various ceremonies, the construction of Pura, and the establishment of traditional institutions in Bali are indeed some activities to maintain a harmonious relationship between the Balinese people with God, with other people and with the natural environment (Windia, 2013). Sutawan (2008) mentioned at least 14 ritual ceremonies at individual farmer level and eight ritual ceremonies by farmer group in Pura Subak located on farmland. In addition, ceremonial and religious ceremonies are also held in approximately 4.849 temples throughout Bali, both common Pura and Sanggah/Merajan (BPS, 2016). On top of that, various cultural lands in Bali become important to be preserved and maintained its existence in order to maintain Balinese culture as capital and asset in Bali tourism development.

One of the cultural land in the Bali area that is important to maintain its existence is the Bali Aga Region. Bali Aga is a sub-tribe of Balinese who generally live in mountainous areas (Reuter, 2002; Wedakarna et al., 2014). As a conservation area, the Bali Aga mountain area has an important and strategic role in maintaining ecosystem stability and hydrologic cycle from upstream to downstream. Direktorat Kehutanan dan Konservasi Sumberdaya Air (2004) reveals that the upstream (mountain) area has particular significance in terms of water function protection. So that, any upstream activity will have an impact on the downstream area in the form of changes in fluctuations in the discharge and sediment transport, as well as the soluble material in the water flow system. Given the area of Bali Aga is a buffer zone of life, the use of cultural land should be directed to sustainable utilization patterns so that benefits and functions can be felt, both in the upstream and downstream areas. Therefore, stakeholder orientation becomes important to know in order to illustrate the direction of current cultural land utilization, whether it has been able to maintain the preservation of the Bali Aga mountainous region as an upstream area. The purposes of this research were to analyze the pattern of cultural land utilization in the Bali Aga Region and to analyze the polarization of stakeholder orientation in the utilization of cultural land in the Bali Aga Region. This research is very appropriate to be done as a first step to conserve and optimize the benefits of cultural lands in Bali, especially in Bali Aga, in the process of ecotourism development and sustainable tourism.

\section{Methods}

Research time and location of data collection The research was conducted from June to November 2016, located in Bali Aga Lesung Mountain Region, in Pedawa Village and Cempaga Village, Buleleng District-Bali. Geographically, this region is included in Watershed Management Unit (SWP DAS) of Saba Daya located at $\mathrm{S}^{\circ} 3^{\prime} 45^{\prime \prime}$ to $\mathrm{S}^{\circ} 20^{\prime}$ and $\mathrm{E} 114^{\circ} 55^{\prime}$ to $\mathrm{E} 115^{\circ} 10^{\prime}$. The boundaries of this area are Bali Sea as north border, SWP Blingkang Anyar Watershed in the east, SWP of Leh Balian and Oten Sungi Watersheds in the south, and SWP of Teluk Kasungan Pancoran as the west border. Being seen from the topography, the study area is located at altitudes between $3,901.051 \mathrm{~m}$ above sea level, with temperatures ranging from $23-31{ }^{\circ} \mathrm{C}$ and air humidity between $77-82 \%$.

Data collection methods: Analysis of pattern of cultural land utilization This analysis is carried out to determine the current condition of cultural land utilization by the Bali Aga community. The cultural land studied in this study is divided into two types of land utilization, namely 1) agricultural land (in the form of rice fields, gardens, and forests) and 2) settlement land. Data from each aspect of the assessment was taken using a closed questionnaire designed with One Score One Indicator Scoring System method (Avenzora, 2008). One Score One Indicator Scoring System Analysis is a model of analysis through the elaboration development of a series of questionnaires in collecting data and evaluating various variables that have been determined by researchers. This analysis is used to illustrate the sustainability of the cultural land utilization patterns of the Bali Aga community, which is by evaluating aspects of cultural land usage based on criteria and indicators developed through literature studies (Table 1). The range of scales used to obtain scores on every aspect of cultural land utilization is 1-7 (a development of the 1-5 Likert scale). The meanings of each score are as follow: one for "very unsustainable", two for "unsustainable", three for "slightly unsustainable", four for "moderate", five for "slightly sustainable", six for "sustainable" and seven for "very sustainable". The higher the value obtained means the cultural land usage has led to a pattern of sustainable land utilization. On the contrary, if the value obtained is lower, the direction of cultural land usage by the community of Bali Aga is considered unsustainable. In addition, on the aspect of the evaluation of cultural land utilization, there is also an analysis of farm income which refers to Soekartawi (2006), as well as spatial settlement area analysis based on Peraturan Menteri Pekerjaan Umum Number 06/PRT/M/2007 on General Guidelines of Spatial Planning of Building and Environment.

Analysis of polarization on stakeholder orientation There are three important data taken to analyze the polarization of stakeholder orientation (community and government) related to the utilization of cultural land, namely: (1) perception, (2) motivation, and (3) preference. Perception data were taken in relation to stakeholder views on cultural land (agriculture and settlement) and ecotourism, 
Table 1 Aspects and criteria for assessing the utilization of cultural land

\begin{tabular}{|c|c|c|}
\hline No & $\begin{array}{l}\text { Assessment } \\
\text { aspects }\end{array}$ & Assessment criteria \\
\hline 1. & & Agricultural land \\
\hline a. & $\begin{array}{l}\text { Ownership } \\
\text { aspect }\end{array}$ & $\begin{array}{l}\text { The ownership aspect becomes one of the main parameters in describing the strength of land ownership by the } \\
\text { community in order to support the sustainability of agricultural land. By examining this aspect, it can be } \\
\text { described as: 1) the subject of land ownership (indigenous or immigrant), 2) land certification form and 3) land } \\
\text { ownership status. }\end{array}$ \\
\hline b. & $\begin{array}{l}\text { Economic } \\
\text { aspect }\end{array}$ & $\begin{array}{l}\text { Economic aspect becomes important to be studied in order to see how far the feasibility of farming done by } \\
\text { society can fulfill various requirement of life and improve its life standard. The various criteria in the } \\
\text { economic aspects studied include the ability of agricultural land to produce certain commodities on an } \\
\text { economic scale in the fulfillment of people's living needs and income allowance for side business. }\end{array}$ \\
\hline c. & $\begin{array}{l}\text { Ecological } \\
\text { aspect }\end{array}$ & $\begin{array}{l}\text { The ecological aspect becomes an important study in this study, to illustrate the ability of the community in } \\
\text { maintaining the sustainability of agricultural land resources. This can certainly be traced to know whether land } \\
\text { use by the community has been able to preserve the land resources (soil fertility, soil water function, micro } \\
\text { climate, wildlife and aesthetic value). }\end{array}$ \\
\hline d. & $\begin{array}{l}\text { Socio-cultural } \\
\text { aspect }\end{array}$ & $\begin{array}{l}\text { Social culture is one of the parameters to assess the role of society in maintaining the existence of agricultural } \\
\text { land as the root of Balinese culture. The ability of agricultural land in: the formation of character (cognitive, } \\
\text { affective and motor), the benefits of religious and artistic activities, the protection of historic objects and the } \\
\text { minimization of social jealousy are the criteria traced in this aspect. }\end{array}$ \\
\hline 2. & & Settlement land \\
\hline a. & $\begin{array}{l}\text { Ownership } \\
\text { aspect }\end{array}$ & $\begin{array}{l}\text { Clarity of land status is an absolute requirement in creating sustainable housing development. Therefore, } \\
\text { ownership aspect is one of the main parameters to track the condition of existing land status in residential area. } \\
\text { It examines the issues of ownership, certification and land ownership. }\end{array}$ \\
\hline b. & $\begin{array}{l}\text { Economic } \\
\text { Aspect }\end{array}$ & $\begin{array}{l}\text { The close distance of residential locations with economic centers becomes an important study in the } \\
\text { assessment of the economic aspects of the settlements. This is intended to see to what extent the current } \\
\text { settlement conditions can support ecotourism development. In this case, the related approaches are: 1) } \\
\text { accessibility conditions, infrastructure and public facilities, and 2) proximity of residential locations to } \\
\text { economic centers and tourist destinations. }\end{array}$ \\
\hline c. & $\begin{array}{l}\text { Ecological } \\
\text { aspect }\end{array}$ & $\begin{array}{l}\text { The study of ecological aspects becomes important to do in order to describe the pattern of current community } \\
\text { activity towards the sustainability of the settlement environment. Maintaining the quality and value of } \\
\text { landscape benefits (natural and cultural) and the existence of flora and fauna are the criteria used in the } \\
\text { assessment of ecological aspects of the settlement. }\end{array}$ \\
\hline d. & $\begin{array}{l}\text { Socio-cultural } \\
\text { aspect }\end{array}$ & $\begin{array}{l}\text { Pattern of community land utilization in supporting the existence of local culture is part of the socio-cultural } \\
\text { aspect assessment. The criteria used as a benchmark for assessment on socio-cultural aspects is related to the } \\
\text { seven elements of a universal culture, namely: living equipment system, livelihood, social organization, } \\
\text { language, art, knowledge and religion system. }\end{array}$ \\
\hline e. & Spatial aspect & $\begin{array}{l}\text { Spatial planning is one of the important aspects of the assessment in creating sustainable housing patterns. The } \\
\text { suitability of settlement in spatial area can be studied by describing the characteristics: 1) designation of spatial } \\
\text { and building area, 2) residential land, and 3) allotment of material and building structure. }\end{array}$ \\
\hline
\end{tabular}

motivational data related to the main drivers of stakeholders in the utilization of cultural land and ecotourism development, as well as preference data related to the desire of each stakeholder in the utilization of cultural land. All three data are also taken using a closed questionnaire with One Score One Criteria pattern. Kruskal Wallis and Dunn Tests are used to analyzing the occurrence of polarization. The polarization that occurs can be direction polarization and scale polarization. The direction polarization occurs when the scores between stakeholders are in two different dimensions: Dimension I (score below four) and Dimension II (score above four). Whereas if there is a difference in scores between stakeholders and are in the same dimension (Dimension I/Dimension II), this phenomenon is called scale polarization.

Sampling techniques and research samples The sample in this study was chosen using a purposive sampling method. The sample respondents are stakeholders who are related to the use of cultural land; consists of 5 categories, namely: (1) community owning rice field, (2) community owning farmland, (3) community owning forest land, (4) community owning settlement land, and (5) Buleleng District Government. The number of samples in each category is 30 respondents. The community samples in category $1-4$ were taken from two villages (i.e., Pedawa Village and Cempaga Village) consist of 240 people, while the government of Buleleng consist of 30 people, hence the total number of respondents is 270 people.

\section{Results and Discussion}

The pattern of cultural land utilization: Ownership aspects From the assessment of the criteria of agricultural land ownership and settlement aspects, the average score is 6 
Table 2 Average farm income on agricultural land

\begin{tabular}{lcc}
\hline \multicolumn{1}{c}{ Discription } & \multicolumn{2}{c}{ Value } \\
\cline { 2 - 3 } & Pedawa Village & Cempaga Village \\
\hline Averege land area (ha person & 1.182 & 0.848 \\
Averege revenue (IDR year ${ }^{-1}$ ) & $39,966,818$ & $16,688,194$ \\
Average production cost (IDR year ${ }^{-1}$ ) & $19,121,762$ & $10,801,919$ \\
Averege income (IDR year ${ }^{-1}$ ) & $20,845,056$ & $5,886,275$ \\
\hline
\end{tabular}

(sustainable). It can be understood that: (1) the community currently plays a decision-maker in the utilization of its land, and (2) the community has a good awareness by registering its land for legal legalization (Certificate of Ownership/SHM). The sustainability of the ownership aspect is also supported by high land tenure by the local indigenous people. Low land ownership by migrant communities can certainly minimize the influence of the external culture brought about by migrant communities (Anisa et al., 2010). In addition, the high awareness of the community by registering its land to be legalized positively makes the existing land at this time will be spared from various land disputes in the future. In relation to farming activities, Agustin et al. (2011) disclose that certification of agricultural land is important because the certificates can be used as collateral to obtain banking credit facilities, thus helping farmers obtain farming capital.

Economic aspects The results of the study on the criteria of agricultural land and settlement assessment from the economic aspects, it was obtained an average value of 4 (normal). In terms of agricultural land utilization, the facts in the field show that farmers rely on only one type of agricultural commodity (cloves) in meeting their life needs. Clove commodity is a plantation crop that dominates in the Bali Aga region, as well as being a superior local plantation product. In 2013, the highest clove production was in the District of Banjar, with a total production of 714.70 tons (BPS, 2013). The suitable climatic conditions and topography support the community's motivation to grow clove plants, furthermore, clove plants have been economically sufficient to help the community in meeting their primary needs and labor absorption (especially during the harvesting season). The results of the farming assessment on agricultural land based on income analysis can be seen in Table 2 .

The development of cloves in the Bali Aga region is still relatively newly redeveloped after a period of failure in the 1990 s, which results in the current low income of farmers. Although the clove commodities has yet met the fulfillment of secondary and tertiary needs of farmers, they have an optimistic attitude towards the value of clove commodities in the future, that is, if the government accommodates the community preferences, related to (1) business capital (land provision, especially, for people classified as poor; provision of farm credit programs with low-interest rates; control of price of the production facilities affordable by farmers; and assistance of agricultural tools and technology); (2) agricultural infrastructure (construction of farm roads, irrigation systems, lighting/electricity systems, and construction of wholesale markets); (3) improvement of human resources (capacity building in terms of land preparation, planting, plant care, harvesting and postharvest, how to access business capital, establishment of farmer institutions, and network expansion); (4) marketing (setting the quality standards of agricultural commodities, setting upper and lower limits of prices, exhibition of agricultural products and processed products, and facilitating the product packaging process); and (5) grant assistance programs (in the form of seeds/seedlings, agricultural production facilities, and reduction and/or exemption of land and building tax).

The low income of the people from agricultural land utilization (lower than Minimum Wage of Buleleng Regency IDR22,077,000 year ${ }^{-1}$ ), can be interpreted as one of the severe threats in triggering the land conversion of this area in the future. Causality, the lack of income generated from the farming activities can be one of the causes of the conversion of agricultural land in Bali (Dewi \& Sarjana, 2015). For that matter, ecotourism development becomes a wise choice to increase added value on agricultural land. In agriculture view, agrotourism serves as a diversification effort that can be a source of new growth for both the agricultural sector and the national economy. The Village of Bayung Gede (Bangli District), Candikuning (Tabanan District), Blimbingsari (Jembrana District) and Pelaga (Badung District) are some examples of villages in Bali that have successfully combined the use of agricultural land for agro-tourism activities to provide additional income for the community (Utama, 2012).

The high motivation of the community to maintain the existence of residential land ownership that can be used to produce certain types of businesses in order to achieve the absorption of community employment and an adequate level of income, in reality, has not been supported by adequate accessibility. Results from the assessment of the accessibility conditions of settlements show that Bali Aga Village is located relatively far from the Capital District, with a travel time of more than 2 hours away using two-wheeled vehicles, and there is no public transportation operating to Bali Aga. Silondae (2016) revealed that transportation plays an important role in accommodating the social and economic activities of the community. The development of transportation facilities and infrastructure can open accessibility, thus increasing community production, leading to an increase in people's purchasing power. Based on this, the development of road accessibility, with good and adequate intensity and quality, is important to be carried out. This will enable connecting residential locations with economic centers such as industrial centers, tourist 
attractions, as well as seaports and airports. Furthermore, government support to build sub-terminals, as a transportation link between villages, sub-districts, districts and/or provinces, is also important to be executed so that economic activity can run optimally. This can be done by establishing sub terminals around residential locations with good and adequate quality.

The value of residential land utilization from the economic side is classified as ordinary, caused by several factors, namely accessibility and inadequate infrastructure. On the other hand, Pedawa and Cempaga Villages have several advantages, namely: 1) location on the crossing route of tourists and 2) community plantation land close to residential land so that the plantation can be sold directly in front of the land residence near the crossing track traveler. This is certainly a chance to attract several tourists when they want to pass to buy the results of agriculture and/or traditional food at stalls around the path crossing. Research conducted by (Utama, 2012) indicates that the path of crossing tourism can be used as an area of employment and business opportunities for people who are around the line crossing.

In addition to the importance of accessibility, the community also has preferences for the government to be able to improve the quality of settlements, both in terms of infrastructure and facilities, location, and residential homes. In terms of housing infrastructure and facilities, the community hopes that the government can build and improve the quality of village roads, clean water networks, electricity and telecommunications, drainage systems, environmental sanitation, trade and commercial facilities, health facilities, education, worship and cultural facilities, sports and playground facilities. As for residential location, the government is expected to make the Bali Aga region as a tourist destination. Whereas, regarding the feasibility of residential houses, the community hopes that the government will be able to: (1) cooperate with private institutions or State-Owned Enterprises (BUMN) to create housing renovation programs intended for people classified as poor with good quality and livable types of house with a minimum size of $36 \mathrm{~m}^{2}$, (2) giving a Building Permit (IMB) to the people classified as poor to build residential houses, effectively, efficiently, and with a low cost, (3) impose requirement on the people who build residential houses, to have washing and toilet facilities (MCK), space for organic and non-organic waste, proper sewage and comply with environmental health standards, and (4) actively promotes livable housing (air circulation, lighting, the number of rooms, building materials and structures) to the community, to support the realization of a healthy, safe and sustainable residential environment.

Ecological aspects The average scores obtained from the search on the ecological aspects of agricultural land are five (somewhat sustainable), and the settlement land is six (sustainable). This implies that: 1) the community has a high initiative in careful utilization of land by not degrading the environment and living creatures inside, and 2) the community already understands the positive impact that will be felt if the environment is managed wisely. Sustainability of agricultural land can also be seen from the high motivation of the community to maintain the existence of land functions as a place that is able to assure: the availability and/or sustainability of water systems, microclimate stability, and sustainability of the food chain. The facts in the field show some conditions that cause the non-optimal utilization of agricultural land by the community, such as 1) the use of chemical fertilizers and pesticides and 2) the minimum planting of cover crops on agricultural land (especially clove plantation), that make them vulnerable to erosion. If conservation activities on dry land are not carried out, it will cause erosion, which causes a decline in soil properties (physical, chemical, and biological) and decreases land productivity (Idjudin, 2011). Erfandi (2013) adds that the use of ground cover crops is essential to do because it can add soil organic matter, and it also serves to inhibit the direct impact of rainwater with the soil surface; so that it can inhibit the erosion of soil on clove plantation land.

In order to create ecological sustainability of agricultural land in the Bali Aga region, which has a hilly and quite steep landscape, the community has several preferences to the government, including (1) providing technical assistance related to soil and water conservation on community agricultural land with a slope of $30 \%$ or more, (2) the application of organic farming systems to farmers, (3) distribution of plant seedlings to the community for reforestation activities that meet the land suitability criteria, (4) no alteration on the function of forest areas in the Bali Aga or surrounding areas for other purposes, (5) no altering of the landscape and/or converting the productive land of agriculture for infrastructure development, (6) uphold the law and giving a deterrent effect to the community or government officials who carry out illegal logging and theft of wildlife where legal action is carried out objectively and accountable according to the law applies, and (7) plays an active role in socializing the importance of using agricultural land wisely and create environmental balance.

Regarding the use of residential land, the community has a high motivation to maintain the existence of land functions as a place that can assure the preservation of a healthy, safe and comfortable environment/human ecology and aesthetic value in a landscape. Through the planting of perennials plants around residential areas and community initiatives to install banners with preservation of wild flora and fauna theme, these make Bali Aga settlements protected from natural disasters (e.g., landslides and floods) and degradation of flora and fauna; which currently occurs infrequent to residential areas that do not comply with the principle of ecological sustainability. Research conducted by Effendi (2008) shows that one of the causes of the landslide is land utilization that does not pay attention to soil and water conservation principles. Thus it triggers natural disasters in the form of a landslide.

Socio-cultural aspects Based on the results of the search criteria of agricultural land use and sustainable settlement, the average score is five (somewhat sustainable). This value is obtained from the assessment of the existing socio-cultural conditions and the motivation of the local community in supporting the sustainability of agricultural land and settlements in the Bali Aga region. In terms of agricultural 
land use, the community has a high motivation to maintain the existence of land ownership as a place to preserve social organizations and local cultural customs. The community has put local wisdom as the basis for creating harmonious relations with the environment. The application of local wisdom in the form of subak organization is one of the strong desire of the community to defend the agricultural land along with the various ceremonial activities inside; as a manifestation of the concept of Tri Hita Karana which creates a harmonious relationship between God, the environment and society (Lestari et al., 2015). The concept of Tri Hita Karana, which is still applied by the community on agricultural land, can be an advantage in ecotourism development in the future. Sukerada et al. (2013) indicate that the application of the concept of Tri Hita Karana has an important position in the development of the tourist area is to maintain the continuity of ceremonial activities and environmental sustainability and security in the region.

In the context of settlement land use, the community has been able to maintain the integrity of local indigenous identity and always uphold the customs that exist in everyday life. Maintaining the authenticity of community culture uniqueness can certainly be used as a potential ecotourism resource in attracting tourists. According to Bricker (2007), about $62 \%$ of ecotourists from the United States believe that learning and experiencing other people's cultures are different from their own culture is important. By looking at the phenomenon of the development of cultural tourism in Bali, where the driving factors and attracting tourists are the cultural and historical attractions (Manik et al., 2016), maintaining local culture is the best option to create sustainable ecotourism development in the Bali Aga region.

The solid socio-cultural condition felt in the Bali Aga Region, obviously requires the participation of various stakeholders to support the Bali Aga culture preservation, universally. The seven universal cultural elements include technology and systems of living equipment, livelihoods, social organization systems, languages, arts, systems of knowledge, and religion (Liliweri, 2014). In order to achieve sustainability in the seven universal cultures, the community has urged the government to facilitate and/or guide them on the following aspects: (1) preservation of local wisdom (traditional rituals in agricultural activities and traditional ceremonies in the area of community settlements), (2) implementation of work program of social organizations (religious, economic, educational, legal and security), (3) preservation of living equipment systems (traditional clothing, and agricultural and household furnishings/tools) that are both traditional and modern without degrading the environmental or cultural values, (4) preserve regional and Indonesian languages, verbally and in writing, without degrading the cultural values of local communities, (5) organizing spiritual/religious activities, and (6) organizing art festivals (music, dance, and drama) as well as harvesting festivals of agricultural products as a tourism promotion event.

Aspects of spatial planning From the results of the assessment of the criteria of settlement land utilization, the average score is 6 (sustainable). This means that: (1) the community has built a pattern of settlement in accordance with the applicable positive law, (2) the community still maintains the existence of local culture, which is proved by the application of local wisdom in every settlement development, and (3) the community is able to keep the settlement area avoided from environmental degradation while creating aesthetic value of the settlement. The results of the assessment of the characteristics of residential land and their buildings based on the analysis of spatial settlement areas in the community can be seen in Table 3 .

The adoption of local wisdom and the suitability of settlement patterns with existing positive law in making the future residential areas can be designed and managed easily for sustainable land development. Some local wisdom in terms of utilization of residential land that is still implemented by the people of Bali Aga, namely: (1) the concept of Natah, (2) the concept of Tri Mandala, and (3) Tri Angga concept. Dwijendra (2010) mentions that the

Table 3 Characteristics of land and buildings in community settlements

\begin{tabular}{lrr}
\hline \multicolumn{1}{c}{ Description } & \multicolumn{2}{c}{ Value } \\
\cline { 2 - 3 } & Pedawa Village & Cempaga Village \\
\hline Residental area $\left(\mathrm{m}^{2}\right)$ & 376.25 & 324.13 \\
Building area $(\mathrm{m})$ & 72.70 & 74.95 \\
Building floor area $\left(\mathrm{m}^{2}\right)$ & 74.04 & 77.63 \\
Number of building floors & 1.02 & 1.02 \\
Height of building $(\mathrm{m})$ & 2.63 & 2.62 \\
Open space $(\mathrm{m})$ & 302.21 & 247.31 \\
Green open space $(\mathrm{m})$ & 120.94 & 107.40 \\
Road width $(\mathrm{m})$ & 2.37 & 2.11 \\
Front border line/FBL $(\mathrm{m})$ & 5.89 & 3.66 \\
Left building border line/LBBL $(\mathrm{m})$ & 2.09 & 1.94 \\
Right building border line/RBBL $(\mathrm{m})$ & 2.33 & 8.41 \\
Behind rear border line/BRBL $(\mathrm{m})$ & 2.56 & 1.91 \\
\hline
\end{tabular}


application of the concept of Natah, Tri Mandala, and Tri Angga by the Balinese people on residential land, is an action to create a balance of life between the residential environment and its inhabitants. The application of these three concepts is not only implemented by the Balinese people in general, but the concept is also applicable to the Balinese Aga in creating a balance of settlement environment (Rifza \& Amos, 2016; Winawangsari et al., 2017). Illustration of the spatial layout of residential buildings of the Bali Aga community can be seen in Figure 1.

The results of field research indicate that the construction of each land settlement has been in accordance with the permit designation of materials and building structures. In terms of the conformity of the designation permit of building materials, the Bali Aga community has classified materials that can be used for the construction of a temple and shelter. In terms of building a place of worship, the people of Bali Aga are very concerned about the sanctity of a material, especially in the form of wood. The type of wood used in the manufacture of Merajan/Sanggah is a type of wood that is classified as a sacred wood, namely, jackfruit wood. While in residential buildings, the use of materials used is more flexible than the place praying. The people of Bali Aga give restrictions on the type of wood that is not allowed to be used as a building material of the residence, namely jackfruit wood.

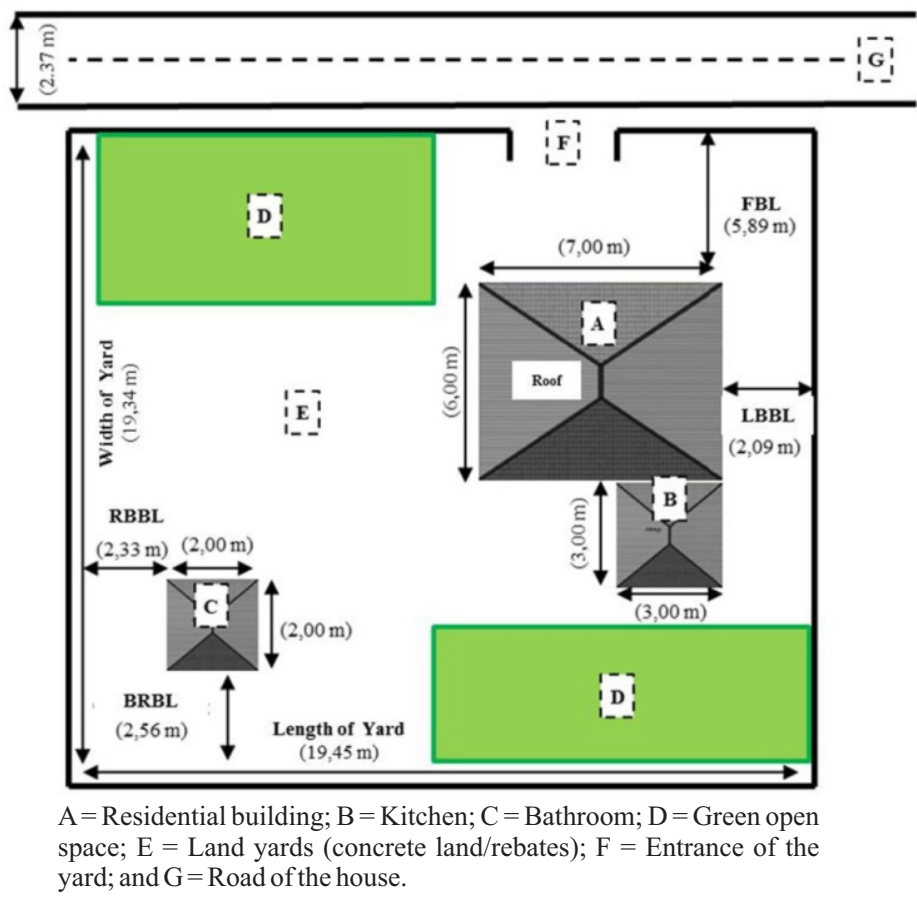

Figure 1 Spatial building layout sased on the Natah concept.

a. Concept of Tri Mandala

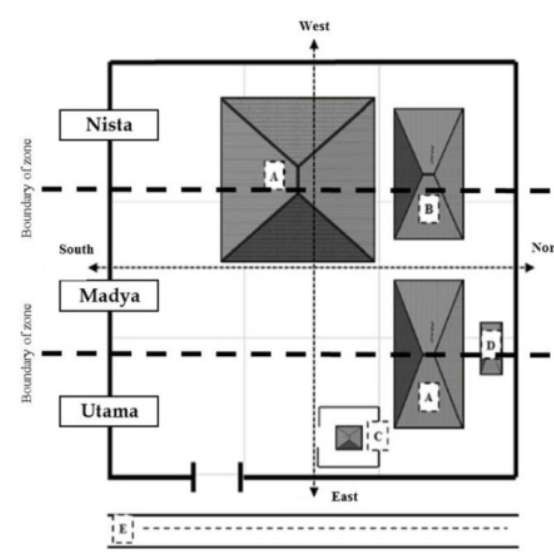

$\mathbf{A}=$ Residential building, $\mathbf{B}=$ Kitchen, $\mathbf{C}=$ Place of worship of the family (Merajan), $\mathbf{D}=$ Sanggah nganten, and $\mathbf{E}=$ Road home b. Concept of Tri Angga
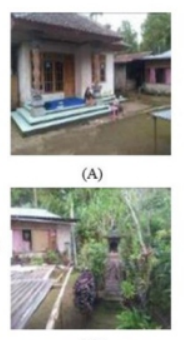

(C)

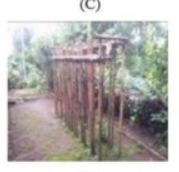

(D)

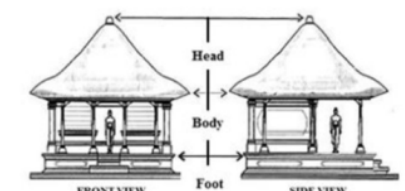

Implementation of Tri Angga Concept

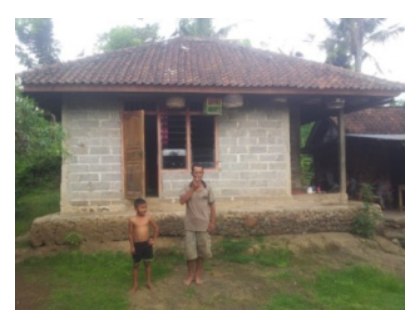

Figure 2 Spatial planning of home building based on Tri Mandala and Tri Angga concepts. 
In the context of conformity permit designation of building structures, research results in the field show that the people of Bali Aga has applied the typical Balinese architecture in the building where he lived. In the concept of traditional Balinese architecture, Balinese Aga refers to the concept of Tri Mandala and Tri Angga (Figure 2). Tri Mandala is a concept of structuring the building based on horizontal values, i.e., placing sacred activities in the Utama Mandala areas, worldly activities at the Madya Mandala, and activities that are considered dirty and containing waste are in the Nista Mandala zone. While Tri Angga is a concept that gives the direction of values in a vertical, consists of three parts that are described as the structure in the human body that is the top (head), middle (body), and the bottom is the foot (Dwijendra, 2003).

Polarization on stakeholder orientation in cultural land utilization and ccotourism: Polarization on stakeholder perception in cultural land utilization and ccotourism The result of Kruskal Walls and Dunn tests shows that there are nine criteria of 14 criteria of perception assessment in the utilization of cultural land and ecotourism that have perceptible polarization significantly, namely (1) agricultural ecology, (2) residential economy, (3) settlement ecology, (4) settlement socio-culture, (5) ecotourism (negative), (6) ecotourism economic impact (negative), (7) ecotourism ecological impact (negative), (8) ecotourism socio-cultural impact (positive), and (9) ecotourism socio-cultural impact (negative). While the five criteria which do not experience perception polarization are (1) agricultural economy, (2) agricultural socio-culture, (3) ecotourism (positive), (4) ecotourism economic impact (positive), and 5) ecotourism ecological impact (positive). The results of perceptual polarization assessment in the utilization of cultural land and ecotourism can be seen in Figure 3.

In terms of perceptions of cultural land utilization, the results of studies show that there has been a scale polarization between stakeholders (Figure 3). Polarization occurs mainly in the economic aspects of residential land (point D). Different perceptions among stakeholders are motivated by the cultural condition of Balinese Aga people who still view residential land as a limited place only for shelter without use for agricultural or livestock activities. The community has the belief that if the settlement is used for agriculture and livestock activities, negative energy will enter the house so that it will cause a disaster (disease, distress, and others). In line with the phenomenon, Saliem (1997) revealed that socio-cultural conditions of society are one of the government obstacles in the implementation of the program optimization of land use yards. In addition, agricultural and livestock activities cannot be implemented in the residential areas of Bali Aga because the ownership of agricultural land is still relatively large. Hence, people prefer to do farming on land.

Scale polarization also occurs in the context of ecotourism and the impact of ecotourism, particularly concerning negative perceptions (Figure 3). The score of four (ordinary course) government stakeholders and community stakeholders worth two (disagree), can mean that the government has not fully grasped the importance of ecotourism concepts in creating sustainable land use. Therefore, efforts should be made is to increase the capacity and insight of the state apparatus in understanding the various elements contained in the concept of ecotourism. With a good understanding of ecotourism, governments will naturally realize that the concept is an important concept to create sustainable use of cultural land. As revealed by

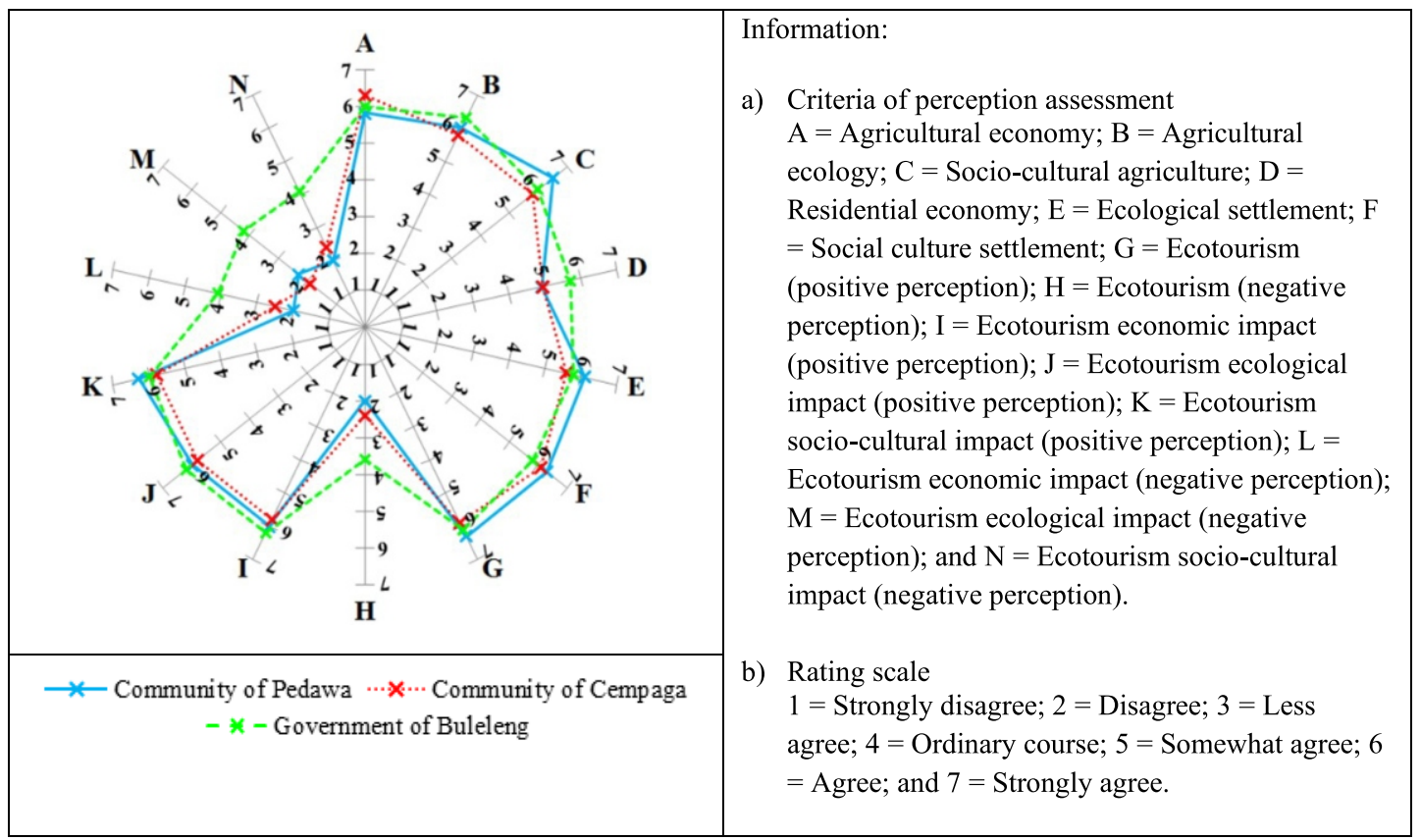

Figure 3 Polarization on stakeholder perception in cultural land utilization and ecotourism. 
Snyman (2014), ecotourism is one alternative to creating sustainable land use, developing the local economy, and improve the social movements of the biodiversity conservation.

Polarization on stakeholder motivation in cultural land utilization and ecotourism Based on Kruskal Wallis and Dunn's test analysis on five motivation criteria, the result is that there is no motivation polarization on the criteria of agricultural land use and settlement land use. Meanwhile, in the context of ecotourism development, the analysis shows that there has been a significant scale polarization in 3 criteria, namely: (1) ecotourism economy, (2) ecotourism ecology, and (3) socio-cultural ecotourism. The result of the polarization assessment of motivation in the utilization of cultural land and ecotourism can be seen in Figure 4.

In terms of motivation in the utilization of cultural land, the phenomenon of polarization does not occur between stakeholders (Figure 4). This indicates that stakeholders have a serious concern in maintaining the existence of cultural land in the area of Bali Aga, in order to be used as a place for economic activity, place of ecological activity, place of ritual activity, and religion of society.

In the context of ecotourism motivation, scale polarization occurs on the criteria of economic, ecological, and socio-cultural assessment (Figure 4). Motivational differences in the three assessment criteria remain in a positive dimension and lead to an orientation that supports ecotourism development. The high motivation of stakeholders in ecotourism development indicates that the community and government are ready to participate and play an active role in ecotourism activities. Stakeholder participation in ecotourism development can certainly serve as one of the reasons for establishing the Bali Aga area as an ecotourism area. The result of research by Ratnaningsih \& Mahagangga (2015) revealed that after the declaration of a village as a tourist village, the villagers are getting harder with the community to discuss the program and the planning that will be done to support tourism activities, which in the future is expected to improve the economy of the community.

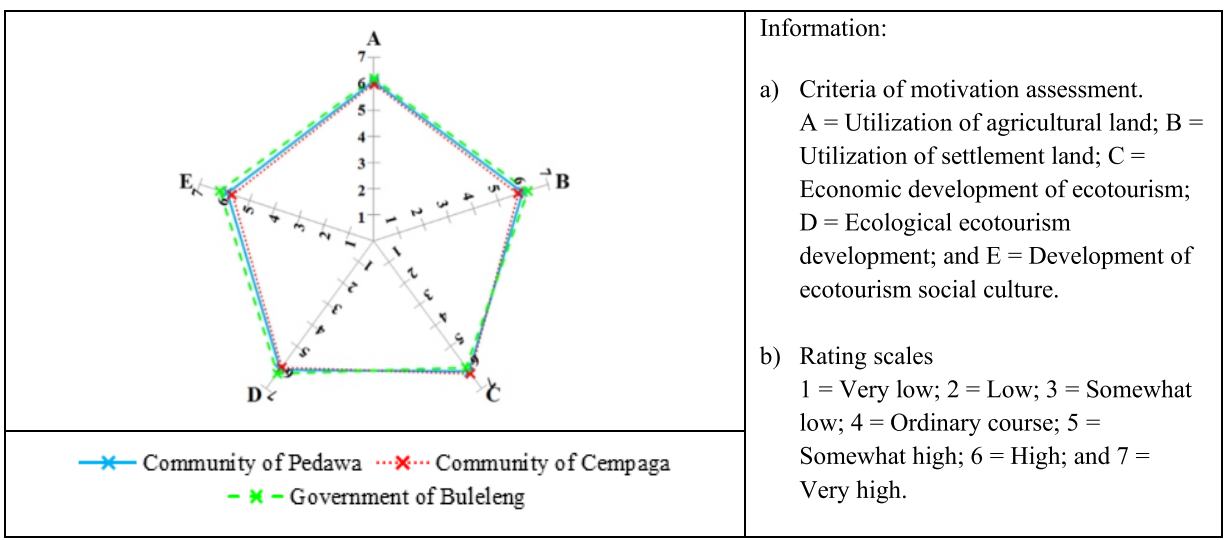

Figure 4 Polarization on stakeholder motivation in cultural land utilization and ecotourism.

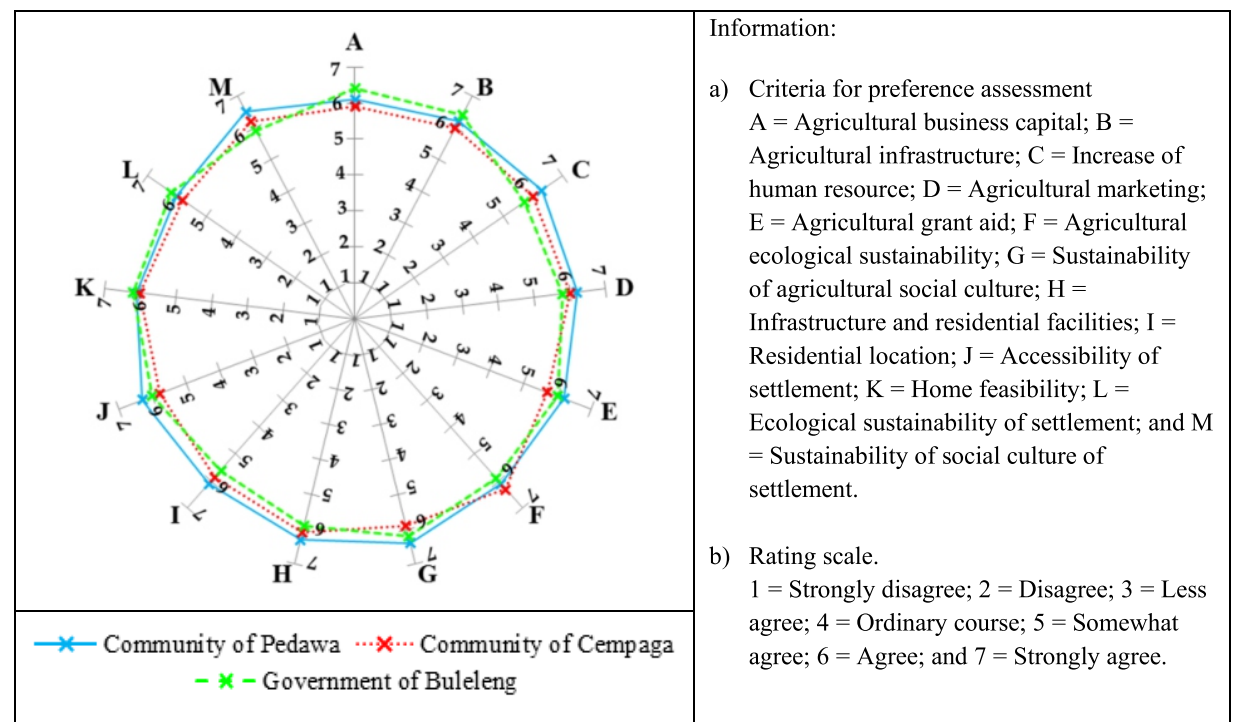

Figure 5 Polarization on stakeholder preference in cultural land utilization. 
Polarization on stakeholder preference in cultural land utilization From the results of Kruskal Walls and Dunn tests on 13 criteria for preference assessment, 12 criteria were experienced significant scale polarization, and one criterion did not experience polarization. The twelve criteria that have polarization scale, namely: (1) business capital, (2) agricultural infrastructure, (3) human resources improvement, (4) marketing, (5) grant aid, (6) sustainability of agricultural ecology, 7) socio-cultural preservation culture, (8) infrastructure and residential facilities, (9) residential location, (10) residential accessibility, (11) residential ecological sustainability, and (12) social preservation of settlement culture. While 1 criterion that does not experience polarization is the feasibility of home. The result of the preference polarization assessment in the utilization of cultural land can be seen in Figure 5 .

Figure 5 shows that the study of preferences in the utilization of cultural land is divided into two categories of assessment, namely: 1) agricultural land utilization in point $\mathrm{A}$ to $G$, and 2) settlement land utilization in point $H$ to $M$. In the context of agricultural land utilization, scale polarization occurs in all assessment criteria. This means that there is still a difference in desire between stakeholders, although the scores on each score are not far behind and still on a continuous orientation. The high value of community preference with a score of six in agricultural land use indicates that the community has a strong desire to increase the economic, ecological, and socio-cultural values found in agricultural land, in order to maintain the existence and sustainability of the land. Therefore, the provision of venture capital, improvement of agricultural infrastructure, marketing assistance, and grant aid to the community is an action that must be done by the government to strengthen the economic value and productivity of agricultural land. This is in line with Shinta's (2011) research, which says that business capital aid, agricultural infrastructure, community empowerment, marketing, and grant aid are important elements in increasing agricultural production.

In terms of ecological and socio-culture sustainability, people hope to the government to be able to make implementation regulations and programs in supporting the sustainability of agricultural land. The programs that should be done by the government in supporting the sustainability of agricultural land are: (1) facilitating the community in the development of organic agriculture, (2) doing soil and water conservation, (3) conducting periodic socialization in terms of environmental conservation, and (4) facilitating the community in making customary rules, in order to protect the quantity of existing agricultural land, as the cultural root of Balinese society.

Regarding the utilization of residential land, the scale polarization occurs between the community and the government (Figure 5). Despite the scale polarization, the difference in value between stakeholders is not much different and still leads to a sustainable orientation. Facts in the field show that the government has limitations in the development of residential areas in the Village of Bali Aga (physical development, ecological, and socio-cultural preservation). Therefore the government hopes to the community to participate actively in assisting the government's limitations. Musliyatun (2016) states that community involvement is necessary for achieving the success of village development. Without community participation, the development will not work correctly and as expected. Hayati (2017) also revealed that community participation has a considerable influence on the process of building village settlements, especially in terms of infrastructure.

In terms of ecological and socio-cultural sustainability of settlements, the community hopes to the government that the development program always applies the principles of sustainability of the settlement and cares about the cultural resources in the Village of Bali Aga. The provision of green open space through the planting of hard crops and community development is an absolute requirement that must be implemented by the government to create ecological balance and environmental comfort for the community. Cultural festivals initiated by the government each year become important to be done in a sustainable manner, in order to increase public interest to participate in cultural preservation, especially the culture of Bali Aga.

Taking into account the various dynamics of cultural land utilization happen as described in the previous section, there are several important worth issues to be discussed: (1) safeguarding cultural land from occupational capitalists (investors) especially in tourism and (2) minimizing strategies polarization between stakeholders in the utilization of cultural land. In the context of efforts to maintain the utilization of cultural land, the community must strengthen the land ownership status in order to be used optimally in fulfilling all the needs of life, both primary, secondary, and tertiary. The existence of the legality of land ownership can provide comfort for the community in managing their land as a whole so beneficial to families and communities in the village.

Strong land ownership of the community is also important in the process of sustainable ecotourism development. In addition, strong land ownership will prevent the community from marginalization in tourism development. Azhar (2013) explained that the loss of land ownership by the community in Ungasan Village (BadungBali) becomes the bitter learning material of negative impact from tourism development. Cooperation between the government and the investors has caused the community's powerlessness to land ownership, resulting in the marginalization of the community in the village. Unproductive conditions of the land in Ungasan Village, the increase of taxes amount to be paid, and the low bargaining power of the community has been exploited by the government to accelerate the land purchase permit to investors as a source of revenue for the local income. In addition, Azhar (2013) revealed that the weak control or supervision of the government and the rise of land brokers are some of the driving factors in the process of land ownership transfer by the Ungasan community.

The right strategy to be done in minimizing the polarization of the stakeholder orientation is by building a shared understanding of the importance of sustainability and sustainability of cultural land as a place to preserve various natural and cultural potentials in the Bali Aga Region. 
Comprehensive understanding and in accordance with the criteria and indicators of sustainable use of cultural land can undoubtedly ensure the sustainability of the existing cultural lands. Criteria and indicators of sustainable use of cultural land can be applied to two types of land use, namely agricultural land, and residential land. In the context of agricultural land, stakeholders are required to be able to: 1) maintain the ownership of agricultural land to be owned by local indigenous peoples, 2) increase productivity of agricultural commodities to meet the needs of the community, 3) safeguard the sustainability of agricultural land resources (soil fertility, soil water function, microclimate, wildlife, and aesthetic value), and 4) maintaining the existence of agricultural land to be utilized in the formation of character, religious activities, arts activities, the protection of historical objects to minimize social jealousy. In terms of settlement land, stakeholders are required to be able to: 1) maintain ownership of settlement land to be controlled by indigenous peoples, 2) improve accessibility, infrastructure and public facilities in residential areas and to tourist destinations; 3) maintain the quality and value of landscape benefits (natural and cultural) and the existence of flora and fauna, 4) maintain and strengthen the quality of the seven cultural elements (living equipment system, livelihood system, social organization, language, arts, knowledge, and religious system) in residential areas, and 5) the suitability of the spatial layout of residential areas based on the positive law and customary law prevailing in the Bali Aga Region.

\section{Conclusion}

The community has implemented various sustainability principles in the utilization of cultural land in the Bali Aga Region. This is evidenced by the behavior of the community in maintaining the integrity of land ownership, cultivating the land by promoting ecological sustainability, using local wisdom in supporting the preservation of the environment, and applying spatial concept based on the positive law and customary law. The sustainable cultural land utilization in the Bali Aga Region has not been fully achieved because the stakeholder orientation on various aspects and assessment criteria still experience polarization. Although the orientation polarization is still at the level of scale polarization, it can certainly trigger future problems if the polarization is not minimized well by various stakeholder elements. Therefore, creating a unidirectional understanding and in accordance with the criteria and indicators of sustainable use of cultural land, the right strategy to be done in maintaining the existence of cultural land in the Bali Aga Region.

\section{Recommendation}

Integrated management of stakeholders is required by building mutual understanding on every aspect of ecotourism development to create sustainable cultural land utilization in supporting ecotourism development. This becomes important to do, as part of creating an orientation alignment so that the benefits of ecotourism will be felt by all stakeholder elements.

\section{References}

Agustin, N. K., Sinuraya, J. F., \& Pasaribu, S. M. (2011). Sertifikasi lahan pertanian mendorong peningkatan produksi pangan. In S. M. Pasaribu, H. P. Saliem, H. Soeparno, E. Pasandaran, \& F. Kasryni, Konversi dan fragmentasi Lahan: Ancaman terhadap kemandirian pangan. Jakarta: IPB Press.

Anisa, Ilham J., \& Purnama, T. (2010). Perubahan pola permukiman masyarakat Betawi di Condet. Inersia, 6(1), 65-72. https://doi.org/10.21831/inersia.v6il.10575.

Ariani, N. M. (2011). Pergulatan otentisitas dan komodifikasi dalam pariwisata budaya. Analisis Pariwisata, 11(1), 27-40.

Avenzora, R. (2008). Penilaian potensi objek wisata: Aspek dan indikator penilaian. In R. Avenzora, Ekoturismeteori dan praktek. Aceh: BRR NAD-Nias.

Avenzora, R. (2013). Ekoturisme: teori dan implikasi. In D. Darusman, \& R. Avenzora, Pembangunan ekowisata pada kawasan hutan produksi: Potensi dan pemikiran. Bogor: Program Pasca Sarjana Institut Pertanian Bogor.

Avenzora, R., Batubara, R. P., Fajrin, R. F., Sagita, E., Armilizia, P. R., Amelia, M., ..., \& Arifullah, N. (2013). Nagari ecotourism in Ranah Minang, West Sumatera: Potential and collaboration dynamics. In F. Teguh, \& R. Avenzora, Ecotourism and sustainable tourism development in Indonesia: Potentials, lessons and best practices. Jakarta: Ministry of Tourism and Creative Economy.

Azhar, M. A. (2013). Marginalisasi masyarakat di daerah pariwisata (Studi kasus di Desa Ungasan Kecamatan Kuta Selatan Kabupaten Badung. Jurnal Ilmiah Administrasi Publik dan Pembangunan, 4(2), 166-176.

Barna, C., Epure, M., \& Vasilescu, R. (2011). Ecotourismconservation of the natural and cultural heritage. Review of Applied Socio-Economic Research, 1(1), 87-96.

Bricker, K. (2007). Overview of ecotourism trends. Washington DC: The International Ecotourism Society.

[BPS] Badan Pusat Statistik. (2013). Statistik pertanian Kabupaten Buleleng 2013. Singaraja: BPS Kabupaten Buleleng.

[BPS] Badan Pusat Statistik. (2016). Provinsi Bali dalam angka. Bali: BPS Provinsi Bali.

Damanik, S. E. (2015). Perencanaan pengembangan wisata alam dan pendidikan lingkungan di kawasan hutan Aek Nauli Kecamatan Lumban Julu. Habonaron Do Bona, 1(1), 18 .

Dewi, I. A. L., \& Sarjana, I. M. (2015). Faktor-faktor pendorong alih fungsi lahan sawah menjadi lahan nonpertanian (Kasus: Subak Kerdung, Kecamatan Denpasar Selatan). Manajemen Agribisnis, 3(2), 163-171. 
Diarta, I. K. S., \& Sari, I. K. (2008). Petunjuk pengembangan ekowisata pantai dan rekreasi perairan. In R. Avenzora, Ekoturisme-teori dan praktek. Aceh: BRR NAD-Nias.

Driscoll, L., Hunt, H., Honey, M., \& Durham, W. (2011). The importance of ecotourism as a development and conservation tool in the Osa Peninsula, Costa Rica. Washington DC: Stanford University.

Dwijendra, N. K. A. (2003). Perumahan dan pemukiman tradisional Bali. Pemukiman "NATAH", 1(1), 8-24.

Dwijendra, N. K. A. (2010). Arsitektur rumah tradisional Bali: Berdasarkan Asta Kosala-Kosali. Denpasar: Udayana University Press.

Effendi, A. D. (2008). Identifikasi kejadian longsor dan faktor-faktor utama penyebabnya di Kecamatan Babakan Madang Kabupaten Bogor [thesis]. Bogor: IPB University.

Effendi, E. (2004). Kajian Model Pengelolaan Daerah Aliran Sungai (DAS) Terpadu. Info Kajian Bappenas. 1(3), 1-19.

Erfandi, D. (2013). Teknik konservasi tanah lahan kering untuk mengatasi degradasi lahan pada Desa MojorejoLamongan. Bumi Lestari, 13(1), 91-97.

Ernawi, I. S. (2009). Kearifan lokal dalam perspektif penataan ruang. In R. Wikantiyoso, \& P. Tutuko, Kearifan lokal dalam perencanaan dan perancangan kota: Untuk mewujudkan arsitektur kota yang brkelanjutan. Malang: Group Konservasi Arsitektur \& Kota.

Hayati, N. (2017). Partisipasi masyarakat dalam pelaksanaan pembangunan infrastruktur di Desa Senyiur Kecamatan Muara Ancalong Kabupaten Kutai Timur. Administrasi Negara, 5(1), 5375-5388.

Idjudin, A. A. (2011). Peranan konservasi lahan dalam pengelolaan perkebunan. Sumberdaya Lahan, 5(2), 103-116

Imron, M. B. (2015). Meretas jalan meningkatkan pendapatan asli daerah (PAD) melalui Desa Wisata Panglipuran Bali. Bima Praja, 7(4), 279-288. https://doi.org/10.21787/jbp.07.2015.279-288

Lascurain, H. C. (1996). Tourism, ecotourism, and protected area. IUCN: Gland, Switzerland and Cambridge. https://doi.org/10.2305/IUCN.CH.1996.7.en

Lash, G. (1997). What is community-based ecotourism. In J. Bornemeier, M. Victor, \& P. B. Durst (Eds.), Proceedings of Ecotourism for Forest Conservation and Community Development. Bangkok: FAO/RAP and RECOFTC.

Lestari, P. F. K., Windia, W., \& Astiti, N. W. S. (2015). Penerapan Tri Hita Karana untuk keberlanjutan sistem Subak yang menjadi warisan budaya dunia: Kasus Subak Wangaya Betan, Kecamatan Penebel, Kabupaten
Tabanan. Manajemen Agribisnis, 3(1), 22-33.

Liliweri, A. (2014). Pengantar studi kebudayaan. Bandung: Nusa Media.

Mahagangga, I. G. A. O., Suryawan, I. B., Nugroho, S., \& Sudana, I. P. (2016). Pemetaan jalur "Paket Wisata Pedesaan" di Desa Wisata Panglipuran Kecamatan Bangli Kabupaten Bangli. Udayana Mengabdi, 15(2), $1-6$.

Manik, G., Suwena, I. K., \& Suardana, I. W. (2016). Faktor pendorong dan penarik wisatawan backpacker mancanegara berwisata ke Bali. IPTA, 4(2), 1-20. https://doi.org/10.24843/IPTA.2016.v04.i02.p04

Musliyatun, T. (2016). Tingkat partisipasi masyarakat terhadap pelaksanaan pembangunan infrastruktur jalan Desa Pelukahan Kecamatan Kuantan Hilir Seberang Kabupaten Kuantan Singungi Provinsi Riau. Jom Fisip, $3(1), 1-15$.

Nugroho, I. (2011). Ekowisata dan pembangunan berkelanjutan. Yogyakarta: Pustaka Belajar.

Page, S. J., \& Dowling R. K. (2002). Ecotourism. Harlow: Pearson Education Limited.

Pangestu, M. E. (2013). Indonesia's commitment to ecotourism and sustainable tourism development. In F. Teguh, \& R. Avenzora, Ecotourism and sustainable tourism development in Indonesia: Potentials, lessons and best practices. Jakarta: Ministry of Tourism and Creative Economy.

Peraturan Menteri Pekerjaan Umum No. 06/PRT/M/2007 tentang Pedoman Umum Rencana Tata Ruang Bangunan dan Lingkungan.

Purnawan, N. L. R., Sardiana, I. K., \& Suranjaya, I. G. (2015). Paket desa tradisional Tenganan sebagai model pengembangan wisata edukasi budaya Bali. In: Makalah Seminar Sains dan Teknologi; Denpasar, October 29-30. Pp 1-7.

Ratnaningsih, N. L. G., \& Mahagangga, I. G. A. O. (2015). Partisipasi masyarakat lokal dalam pariwisata (Studi kasus di Desa Wisata Belimbing, Tabanan, Bali). Destinasi Pariwisata, 3(1), 45-51. https://doi.org/10. 24843/JDEPAR.2015.v03.i01.p06

Reuter, T. A. (2002). Custodians of the sacred mountains: Culture and society in the highlands of Bali. Honolulu: University of Hawai'i Press.

Rifza, H. B., \& Amos, S. (2016). Bali traditional settlement morphology analysis Penglipuran, Kubu Village, Bangli Regency, Bali Province. Journal of Architecture and Built Environment, 43(1), 47-54. https://doi.org/ 10.9744/dimensi.43.1.47-54

Saliem, H. P. (1997). Peranan wanita dalam sistem produksi 
pertanian menunjang program diversifikasi pangan dan gizi. In Suryana, Kebijaksanaan pembangunan pertanian: Analisis kebijaksanaan antisipatif dan responsif. Jakarta: Pusat Penelitian Sosial Ekonomi Pertanian.

Shinta, A. (2011). Ilmu usahatani. Malang: UB Press.

Silondae, S. (2016). Keterkaitan jalur transportasi dan iteraksi ekonomi Kabupaten Konawe Utara dengan kabupaten/kota sekitarnya. Jurnal Progres Ekonomi Pembangunan, 1(1), 4964.

Snyman, S. (2014). The impact of efrican countries. Tourism and Hospitality Research, 14(1), 37-52. https://doi.org/ $10.1177 / 1467358414529435$

Soekartawi. (2006). Analisis usaha tani. Jakarta: Universitas Indonesia Press.

Sukerada, I. K., Sutjipta, I. N., \& Ap, S. I. G. (2013). Penerapan Tri Hita Karana terhadap kawasan agrowisata Buyan dan Tamblingan di Desa Pancasari Kecamatan Sukasada Kabupaten Buleleng. Manajemen Agribisnis,

$$
\text { 1(2), 43-52. }
$$

Sutawan, N. (2008). Organisasi dan manajemen Subak di Bali. Denpasar: Pustaka Bali Post.

Tuwo, A. (2011). Pengelolaan ekowisata pesisir dan laut: Pendekatan ekologi, sosial-ekonomi, kelembagaan, dan sarana wilayah. Surabaya: Brilian Internasional.

Utama, I. G. B. R. (2012). Agrowisata sebagai pariwisata alternatif di Indonesia: Solusi masif pengentasan kemiskinan. Yogyakarta: Deepublish.

Wedakarna, I. G. N. A., Paraniti, A. A. S. P., \& Wiratny, N. K. (2014). Desa tua di Bali Utara: Kebanggaan identitas Bali Aga (Sidatapa, Cempaga, Tigawasa dan Pedawa). Bali: Universitas Mahendradatta.

Winawangsari, D., Hanan, H., \& Martokusumo, W. (2017). Strategy of adaptation of traditional house architecture Bali Aga. International Journal of Research in Engineering and Science (IJRES), 5(8), 1-8.

Windia, W. (2013). Penguatan budaya subak melalui pemberdayaan ptani. Kajian Bali, 3(2), 137-158. 